\title{
PERSEROAN TERBATAS
}

Untuk Memenuhi Tugas Mata Kuliah

\section{ASPEK HUKUM DALAM BISNIS}

Yang Dibimbing Oleh

Retno Sari Dewi,SH, M.Si

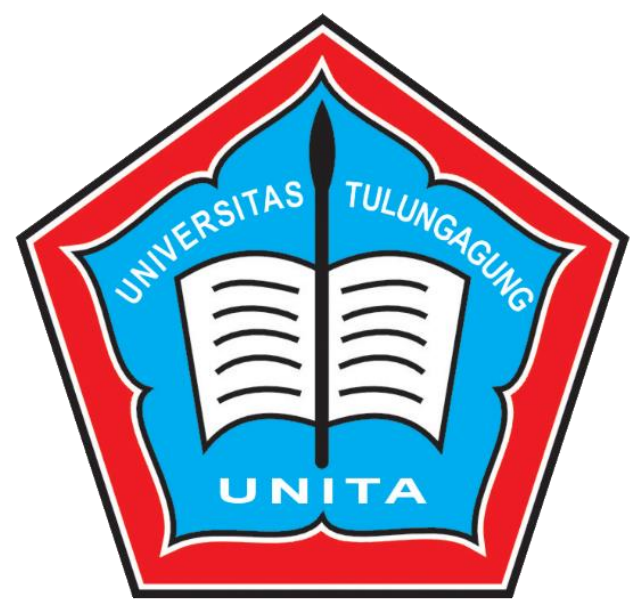

\section{DISUSUN OLEH}

KELOMPOK 2

1. FERY FATUROZI (1860301100038)

2. INDAYU ANINDYA AS (1860301100011)

3. FIFI PERAMASARI (1860301100004)

4. METAMA NARANDIKA (1860301100016)

5. AHMAD SONY SUHARSONO (1860301100051)

6. MOH. ALVIN HENDRAWANTO (1860301100061)

UNIVERSITAS TULUNGAGUNG

FAKULTAS EKONOMI

PRODI AKUNTANSI

2019/2020 


\section{PERSEROAN TERBATAS}

\section{Pengertian Perseroan Terbatas}

Dalam praktek sangat banyak kita jumpai perusahaan berbentuk perusahaan terbatas. Bahkan, berbisnis dengan membentuk perseroan terbatas ini, terutama untuk bisnis yang serius atau bisnis besar merupakan model berbisnis yang paling lazim dilakukan, sehingga dapat dipastikan bahwa jumlah dari perseroan terbatas di Indonesia jauh melebihi jumlah bentuk bisnis lain, seperti Firma, Perusahaan Komanditer, Koperasi dan lain - lain.

Terhadap Perseroan Terbatas ini dalam beberapa bahasa disebut sebagai berikut :

a. Dalam bahasa Inggris disebut dengan Limited (Ltd) Company atau Limited Liability Company; ataupun Limited (Ltd) Corporation;

b. Dalam bahasa Belanda disebut dengan Naamlooze Vennotschap atau yang sering disingkat NV saja

c. Dalam bahasa Jerman terhadap perseroan terbatas ini disebut dengan Gesellschaft mit Beschrankter Haftun, dan;

d. Dalam bahasa Spanyol disebut dengan Sociedad De Responsabilidad Limitada.

Perseroan Terbatas adalah badan hukum yang merupakan persekutuan modal didirikan berdasarkan perjanjian, melakukan kegiatan usaha dengan modal dasar yang seluruhnya terbagi dalam saham dan memenuhi dalam persyaratan yang ditetapkan dalam Undang - Undang Nomor 40 Tahun 2007 tentang Perseroan Terbatas ini serta pelaksanaannya. Untuk menjadi badan hukum, perseroan terbatas harus memenuhi persyaratan dan tata cara pengesahan Perseroan Terbatas sebagaimana yang diatur dalam UUPT, yaitu pengesahan dari Menteri Hukum dan HAM Republik Indonesia. Tata cara tersebut antara lain pengajuan dan pemeriksaan nama Perseroan Terbatas yang akan didirikan, pembuatan Anggaran Dasar, dan pengesahan Anggaran Dasar oleh Menteri.Sebagai persekutuan modal, kekayaan PT terdiri dari modal yang seluruhnya terbagi dalam bentuk saham. Para pendiri PT berkewajiban untuk mengambil bagian modal itu dalam bentuk saham, dan mereka mendapat bukti surat saham sebagai bentuk penyertaan modal. Tanggung jawab pemegang saham terbatas hanya pada modal atau saham yang dimasukkannya ke dalam perseroan (limited liability). 
Segala hutang perseroan tidak dapat ditimpakan kepada harta kekayaan pribadi para pemegang saham, melainkan hanya sebatas modal saham para pemegang saham itu yang disetorkan kepada perseroan. Pendirian PT dilakukan berdasarkan perjanjian. Sebagai sebuah perjanjian, pendirian PT harus harus dilakukan oleh lebih dari satu orang yang saling berjanji untuk mendirikan perseroan, dan mereka yang berjanji itu memasukkan modalnya ke dalam perseroan dalam bentuk saham. Perjanjian tersebut harus dibuat dalam bentuk akta notaris dalam bahasa Indonesia. Notaris yang dimaksud adalah notaris notaris yang wilayah kerjanya sesuai dengan domisili perseroan. Agar sah menjadi badan hukum, akta notaris itu harus disahkan oleh menteri Hukum dan HAM RI. Perseroan Terbatas (PT) adalah suatu perusahaan yang memperoleh modal dengan mengeluarkan surat - surat sero (saham). Tiap - tiap persero memiliki satu sero atau lebih yang mempunyai tanggung jawab terbatas hanya pada modal yang diikut sertakan dalam perusahaan. Perseroan Terbatas adalah badan usaha yang bertujuan mencari keuntungan dan mencapai tujuannya. Permodalan sebuah Perseroan Terbatas terdiri dari saham - saham, jumlah atau besarnya modal ditetapkan dalam anggaran dasar dan tidak boleh diubah (kecuali dengan mengubah seluruh akta notarisnya). Jumlah modal tetap 31 disebut modal statuler. Perseroan Terbatas yang ingin memperbesar modal dengan tidak mengubah statulernya (tidak mengubah akta notaris) dapat mengeluarkan obligasi (surat utang). Obligasi adalah tanda bukti pemiliknya telah memberikan pinjaman sejumlah uang kepada PT penerima obligasi akan menerima balas jasa dalam bentuk bunga dalam persen yang tetap dan tidak menanggung resiko seperti pemegang saham dan preferen yang menerima dividen yang jumlahnya tergantung kecilnya jumlah keuntungan perusahaan. Perseroan Terbatas (PT), dulu disebut juga Naam loze Vennootschaap (NV), adalah suatu persekutuan untuk menjalankan usaha yang memiliki modal terdiri dari saham - saham, yang pemiliknya memiliki bagian sebanyak saham yang dimilikinya. Karena modalnya terdiri dari saham - saham yang dapat diperjual belikan, perubahan kepemilikan perusahaan dapat dilakukan tanpa perlu membubarkan perusahaan. Disamping itu, ada juga yang memberikan arti Perseroan Terbatas sebagai suatu asosiasi pemegang saham (atau bahkan seorang pemegang saham jika dimungkinkan untuk itu oleh hukum di Negara tertentu) yag diciptakan oleh hukum dan diberlakukan sebagai manusia semu (artificial person) oleh pengadilan, yang merupakan badan hukum karenanya sama sekali terpisah dengan orang - orang yang mendirikannya, dengan mempunyai kapasitas untuk bereksistensi yang terus - menerus, dan sebagai suatu badan hukum, perseroan terbatas 
berwenang untuk menerima, memegang dan mengalihkan harta kekayaan, menggugat atau digugat, dan melaksanakan kewenangan - kewenangan lainnya yang diberikan. Definisi - defini

lain yang diberikan kepada suatu perseroan terbatas adalah sebagai berikut:

a. Suatu manusia semu yang diciptakan oleh hukum dari baik 1 (satu) orang anggota (jika hukum memungkinkan untuk itu), yakni disebut dengan perusahaan 1 (satu) orang (corporation sole) maupun yang terdiri dari sekumpulan atau beberapa orang anggota, yakni yang disebut dengan perusahaan banyak orang (corporation aggregate), dan;

b. Suatu badan intelektual (intellectual body) yang diciptakan oleh hukum, yang terdiri dari beberapa orang individu, yang bernaung di bawah 1 (satu) nama bersama, dimana perseroan terbatas tersebut sebagai badan intelektual tetap sama dan eksis meskipun para anggotanya sering berubah - ubah.

Seperti juga tergambar dalam definisi - definisi berubah - ubah seperti diatas, maka menurut hemat peneliti, setidak - tidaknya ada 15 (lima belas) elemen yuridis dari suatu perseroan terbatas berubah - ubah.. Ke 15 (lima belas) elemen yuridis dari perseroan terbatas tersebut adalah sebagai berikut:

a. Dasarnya perjanjian;

b. Adanya para pendiri;

c. Pendiri atau pemegang saham bernaung dibawah suatu nama bersama;

d. Merupakan asosiasi dari pemegang saham atau hanya seorang pemegang saham;

e. Merupakan badan hukum atau manusia semu atau badan intelektual;

f. Diciptakan oleh hukum;

g. Mempunyai kegiatan usaha;

h. Berwenang melakukan kegiatan usahanya sendiri;

i. Kegiatannya termasuk dalam ruang lingkup yang ditentukan oleh perundang - undangan yang berlaku;

j. Adanya modal dasar;

k. Eksistensinya terus berlangsung, meskipun pemegang sahamnya silih berganti;

1. Berwenang menerima, mengalihkan dan memegang asset - asetnya;

$\mathrm{m}$. Dapat menggugat dan digugat di pengadilan;

n. Mempunyai organ perseroan. 
Dari batasan yang diberikan tersebut di atas ada 5 (lima) hal pokok yang dapat kita kemukakan disini:
a. Perseroan terbatas merupakan suatu badan hukum;
b. Didirikan berdasarkan perjanjian;
c. Menjalankan usaha tertentu;
d. Memiliki modal yang terbagi dalam saham - saham, dan;
e. Memenuhi persyaratan Undang -Undang.

Ilmu hukum mengenal 2 (dua) macam subjek hukum, yaitu subjek hukum pribadi (orang perorangan) dan subjek hukum berupa badan hukum. Terhadap masing - masing subjek hukum tersebut berlaku ketentuan hukum yang berbeda satu sama lainnya, meskipun dalam hal - hal tertentu terhadap keduanya dapat diterapkan suatu aturan yang berlaku umum. Salah satu ciri khas yang membedakan subjek hukum pribadi dengan subjek hukum berupa badan hukum adalah saat lahirnya subjek hukum tersebut yang pada akhirnya akan menentukan saat lahirnya hak - hak dan kewajiban bagi masing - masing subjek hukum tersebut. Pada subjek hukum pribadi, status subjek hukum dianggap telah ada bahkan pada saat pribadi orang perorangan tersebut berada dalam kandungan (Pasal 1 ayat (2) Kitab Undang - Undang Hukum Perdata). Sedangkan pada badan hukum, keberadaan status badan hukumnya baru diperoleh set elah ia memperoleh pengesahan dari pejabat yang berwenang yang memberikan hak - hak, kewajiban dan harta kekayaan sendiri bagi badan hukum tersebut. Terlepas dari hak - hak, kewajiban dan harta kekayaan para pendiri, pemegang saham, maupun para pengurusnya. Dalam kitab Undang - Undang Hukum Dagang tidak satu Pasal pun yang menyatakan perseroan sebagai badan hukum, tetapi dalam Undang - Undang Perseroan Terbatas secara tegas dinyatakan dalam Pasal 1 ayat (1) bahwa perseroan adalah badan hukum. Ini berarti perseroan tersebut memenuhi syarat keilmuan sebagai pendukung hak dan kewajiban, antara lain memiliki harta kekayaan sendiri terpisah dari harta kekayaan pendiri atau pengurusnya. Perseroan terbatas merupakan badan usaha dan besarnya modal perseroan tercantum dalam anggaran dasar. Kekayaan perusahaan terpisah dari kekayaan pribadi pemilik perusahaan sehingga memiliki harta kekayaan sendiri. Setiap orang dapat memiliki lebih dari satu saham yang menjadi bukti pemilikan perusahaan. Pemilik saham 
mempunyai tanggung jawab yang terbatas, yaitu sebanyak saham yang dimiliki. Apabila utang perusahaan melebihi kekayaan perusahaan, maka kelebihan utang tersebut tidak menjadi tanggung jawab para pemegang saham. Apabila perusahaan mendapat keuntungan maka keuntungan tersebut dibagikan sesuai dengan ketentuan yang ditetapkan. Pemilik saham akan memperoleh bagian keuntungan yang disebut dividen yang besarnya tergantung pada besar kecilnya keuntungan yang diperoleh perseroan terbatas. Selain berasal dari saham, modal Perseroan Terbatas dapat pula berasal dari obligasi. Keuntungan yang diperoleh para pemilik obligasi adalah mereka mendapatkan bunga tetap tanpa menghiraukan untung atau ruginya perseroan terbatas tersebut

Pengertian Perseroan Terbatas Menurut Undang - Undang Nomor 40 Tahun 2007 tentang Perseroan Terbatas Menurut Pasal 1 ayat (1). Konsep perseroan terbatas dirumuskan dalam Pasal 1 ayat(1) UU No. 40 Tahun 2007 tentang Perseroan Terbatas yang memberikan pengertian bahwa perseroan terbatas, yang selanjutnya disebut perseroan adalah badan hukum yang merupakan persekutuan modal, didirikan berdasarkan perjanjian, melakukan kegiatan usaha dengan modal dasar yang seluruhnya terbagi dalam saham dan memenuhi persyaratan yang ditetapkan dalam undang - undang ini serta peraturan pelaksanaannya. Istilah "perseroan" menunjuk pada cara menentukan modal, yaitu terbagai dalam saham, sedangkan istilah “terbatas" menunjuk pada batas tanggung jawab pemegang saham, yaitu hanya sebatas jumlah nominal saham yang dimiliki. Sebagai badan hukum, perseroan harus memiliki maksud dan tujuan serta kegiatan perseroan yang dicantumkan dalam anggaran dasar. Perseroan harus mempunyai maksud dan tujuan serta kegiatan usaha yang tidak bertentangan dengan ketentuan peraturan perundang - undangan, ketertiban umum, dan atau kesusilaan, sebagaimana ditetapkan dalam Pasal 2 UU No. 40 Tahun 2007. Perseroan yang tidak mencantumkan dengan jelas dan tegas apa maksud dan tujuan serta kegiatan usahanya, dianggap "cacat hukum" (legal defect), sehingga keberadaannya "tidak valid" (invalidate). Perseroan sebagai badan hukum, bermakna bahwa perseroan merupakanlah suatu subjek hukum, dimana perseroan sebagai sebuah badan yang dapat dibebani hak dan kewajiban seperti halnya manusia. Subjek hukum adalah sesuatu yang dapat atau cakap melakukan perbuatan hukum atau melakukan tindakan perdata atau membuat suatu perikatan. Subjek hukum yang dikenal oleh para ahli hukum ada dua macam, yaitu:

a. Orang pribadi (Belanda: naturlijk person atau Inggris: natural person);

b. Badan hukum (Belanda: rechtpersoon atau Inggris: legal entity). 
Unsur utama dari badan hukum adalah apa yang disebut "separate patrimony", yaitu memiliki harta sendiri yang terpisah dari pemegang saham sebagai pemilik. Karakteristik kedua dari badan hukum adalah tanggung jawab terbatas dari pemegang saham sebagai pemilik perusahaan dan pengurus perusahaan.

\section{Dasar Hukum Perseroan Terbatas}

Perusahaan merupakan wadah bagi pengusaha dalam menjalankan bisnisnya di Indonesia dan agar pengusaha bebas dalam menjalankan bisnisnya perlu adanya suatu kepastian hukum yang berlaku, dari banyak jenis perusahaan hanya ada satu perusahaan yang berbadan hukum yang diakui oleh hukum di Indonesia yaitu Perseroan Terbatas (PT).

Ciri khas yang dimiliki oleh badan hukum berbentuk PT adalah :

a. Merupakan bentuk persekutuan yang berbadan hukum diakui di Indonesia;

b. Merupakan kumpulan modal atau saham;

c. Memiliki kekayaan yang yang terpisah dari kekayaan perusahaannya;

d. Pemegang saham memiliki tanggung jawab yang terbatas hanya pada lembar saham yang dimilikinya;

e. Adanya pemisahan tugas pemegang saham dan pengurus atau direksi agar tercipta perusahaan yang sehat;

f. Memiliki komisaris yang berfungsi sebagai pengawas jalannya perusahaan;

g. Kekuasaan tertinggi berada pada RUPS yang diselenggarakan bisanya 1 (satu) tahun sekali.

PT merupakan bentuk perusahaan yang diakui oleh hukum di Indonesia. Dasar hokum pembentukan PT masing - masing sebagai berikut :

a. PT Tertutup : berdasarkan Undang - Undang Nomor. 40/2007 tentang Perseroan Terbatas;

b. PT Terbuka (go public) : berdasarkan UU No. 40/2007 dan UU No. 8/1995 tentang Pasar Modal;

c. PT. PMDN : berdasarkan UU No. 6/1968 juncto UU No. 12/1970

d. PT. PMA : berdasarkan UU No. 1/1967 juncto UU No. 11/1970 tentang PMA

e. PT. PERSERO : berdasarkan UU No. 9/1968 tentangBentuk - Bentuk Usaha Negara juncto PP No. 12/1998 tentang Perusahaan Perseroan, dan; 
f. PT. PERSERO: berdasarkan UU No. 9/1968 tentang Bentuk - Bentuk Usaha Negara joncto PP No. 12/1998 tentang Perusahaan Perseroan.

\section{$\underline{\text { Ciri-Ciri Perseroan Terbatas }}$}

Karakteritik suatu badan usaha dapat digunakan untuk melakukan analisis apakah badan usaha tersebut termasuk PT atau tidak. Mengacu pada pengertian CV di atas, berikut ini adalah ciri-ciri perseroan terbatas:

- Pendirian PT bertujuan untuk mencari keuntungan (profit oriented).

- Perseroan Terbatas memiliki fungsi ekonomi dan fungsi komersial.

- Modal Perseroan Terbatas berasal dari saham-saham dan obligasi.

- Perseroan Terbatas tidak mendapatkan fasilitas dari negara.

- Kekuasaan tertinggi pada Perseroan Terbatas ditentukan melalui Rapat Umum Pemegam Saham (RUPS).

- Pemilik saham memiliki tanggungjawab terhadap perusahaan sebesar modal yang disetorkannya.

- Keuntungan yang didapatkan oleh pemilik saham adalah dalam bentuk deviden (pembagian hasil).

- Perusahaan dipimpin oleh direksi.

\section{$\underline{\text { Jenis-Jenis Perseroan Terbatas (PT) }}$}

Dalam praktiknya, jenis Perseroan Terbatas (PT) terdiri dari:

1. Dilihat dari segi kepemilikannya, antara lain:

a. Perseroan Terbatas Biasa, yaitu merupakan PT dimana para pendiri, pemegang saham, dan pengurusnya adalah warga negara Indonesia dan Badan Hukum Indonesia (dalam pengertian tidak ada modal asing). 
b. Perseroan Terbatas Terbuka, yaitu merupakan PT yang didirikan dalam rangka penanaman modal dan dimungkinkan warga negara asing dan/atau badan hukum asing menjadi pendiri, pemegang saham, dan/atau pengurusnya dari PT tersebut.

c. Perseroan Terbatas PERSERO, yaitu merupakan PT yang dimiliki oleh pemerintah melalui Badan Usaha Milik Negara (BUMN). Perseroan Terbatas ini sebagian besar pengaturannya tunduk pada ketentuan tantang Badan Usaha Milik Negara. Biasanya perusahaan jenis ini kata persero ditulis di belakang nama Perseroan Terbatas tersebut. Contohnya PT Telkom (Persero).

2. Dilihat dari segi status Perseroan Terbatas dibagi dalam:

a. Perseroan Tertutup, yaitu merupakan Perseroan Terbatas yang modal dan jumlah pemegang sahamnya memenuhi kriteria tertentu atau perseroan dan tidak melakukan penawaran umum.

b. Perseroan Terbuka, yaitu merupakan perseroan yang modal dan jumlah pemegang sahamnya memenuhi kriteria tertentu atau perseroan yang melakukan penawaran umum, sesuai dengan peraturan perundang- undangan di bidang pasar modal. Pemberian nama PT jenis ini biasanya disertai dengan singkatan "Tbk" di belakang nama PT tersebut. Contoh PT. Astra Agro Lestari Tbk yang merupakan induk perusahaan dari PT. Sari Lembah Subur Kabupaten Pelalawan (tempat penelitian ini).

Seperti yang telah dijelaskan di atas bahwa Perseroan Terbatas memiliki modal tertentu yang dipersyaratkan. Artinya, besarnya modal sesuai dengan peraturan yang berlaku. Dalam praktiknya modal Perseroan Terbatas terdiri dari:

1. Modal Dasar (Authorized Capital)

Merupakan modal yang pertama kalidan tertera dalam akta notaris pada saat PT tersebut didirikan. Misalnya, PT. Astra Agro Lestari Tbk, didirikan dengan modal dasar Rp. 1.000.000.000,- (satu milyar rupiah) yang tentunya dalam bentuk saham. 
2. Modal Ditempatkan atau Dikeluarkan (Issued Capital)

Merupakan modal yang telah ditempatkan atau dikeluarkan para pemegang saham. Besarnya modal ditempatkan minimal 25\% dari modal dasar. Dari contoh di atas modal ditempatkan adalah sejumlah Rp. 250.000.000,- (dua ratus lima puluh juta rupiah) yang diperoleh dari $25 \%$ dikalikan modal dasar (Rp. 1.000.000.000,-).

3. Modal Setor (Paid-up Capital)

Merupakan modal yang harus sudah disetor oleh pemegang saham yang jumlahnya sebesar 50\% dari modal ditempatkan. Dari contoh di atas besarnya modal setor adalah Rp. 125.000.000,- (seratus dua puluh lima juta rupiah) yang diperoleh dari 50\% dikalikan modal ditempatkan (Rp.250.000.000,-).

Persyaratan untuk mendirikan Perseroan Terbatas adalah harus sesuai dengan peraturan perundang-undangan dan melalui prosedur yang berlaku Tata cara mendirikan Perseroan Terbatas dan syarat-syarat yang harus dipenuhi untuk pendirian tersebut adalah sebagai berikut:

1. PT didirikan sekurang-kurangnya oleh 2 orang

2. Pendirian PT dituangkan dalam Akta Notaris

3. Bahasa yang digunakan adalah bahasa Indonesia

4. Mencantumkan perkataan "PT" dalam Akta Notaris

5. Disahkan oleh Menteri Kehakiman

6. Didaftarkan berdasarkan Undang-undang Wajib Daftar Perusahaan

7. Diumumkan dalam Berita Negara

8. Memiliki modal dasar sekurang-kuranngnya Rp. 20.000.000,- 9dua puluh juta rupiah)

9. Modal ditempatkan sekurang-kurangnya $25 \%$ dari modal dasar

10. Menyetor Modal Setor 50\% dari modal ditempatkan pada saat perusahaan didirikan. 
Demikian pula bagi Perseroan Terbatas yang mengalami perubahan dipersyaratkan untuk:

1. Mencantumkan nama, maksud, dan tujuan kegiatan perseroan

2. Perpanjangan jangka waktu perseroan

3. Peningkatan atau penurunan modal

4. Perubahan status perseroan terbatas dari tertutup menjadi terbuka atau sebaliknya.

Untuk mendirikan PT, harus dengan menggunakan akta notaris yang di dalamnya dicantumkan nama lain dari perseroan terbatas antara lain: Modal, Bidang usaha, Alamat perusahaan dan lainlain. Akta ini harus disahkan oleh Menteri Hukum dan HAM Republik Indonesia, untuk mendapat izin harus memenuhi syarat-syarat sebagai berikut:

1. Perseroan Terbatas tidak bertentangan dengan ketertiban umum dan kesusilaan.

2. Akta pendirian harus memenuhi syarat-syarat yang ditetapkan Undang- undang.

3. Modal yang ditempatkan paling sedikit dan disetor adalah 25\% dari Modal dasar. (Sesuai dengan UU No. 1 Tahun 1995 dan UU No. 40 Tahun 2007, keduanya tentang perseroan terbatas).

Setelah mendapat pengesahan, dahulu sebelum adanya UU mengenai perseroan terbatas (UUNo. 1 Tahun 1995) Perseroan Terbatas harus didaftarkan ke Pengadilan Negeri setempat, tetapi setelah berlakunya UU No.1 Tahun 1995 tersebut, maka akta pendirian tersebut harus didaftarkan ke Kantor Pendaftaran Perusahaan sehingga tidak perlu lagi didaftarkan ke Pengadilan Negeri. Namun selanjutnya, sesuai UU No. 40 Tahun 2007 kewajiban pendaftaran di Kantor Pendaftaran Perusahaan tersebut ditiadakan juga. Sedangkan tahapan pengumuman dalam Berita Negara Republik Indonesia (BNRI) tetap berlaku, hanya yang pada saat UU No. 1 Tahun 1995 berlaku pengumuman tersebut merupakan kewajiban Direksi PT yang bersangkutan. Tetapi sesuai dengan UU No. 40 tahun 2007 diubah menjadi merupakan kewenangan/kewajiban Menteri Hukum dan HAM. 
Setelah tahap tersebut dilalui maka perseroan telah sah sebagai badan hukum dan perseroan terbatas menjadi dirinya sendiri serta dapat melakukan perjanjian-perjanjian, dan kekayaan PT terpisah dari kekayaan pemiliknya.

\section{$\underline{\text { Kelebihan dan Kekurangan Perseroan Terbatas (PT) }}$}

Semua jenis badan usaha pasti memiliki kelebihan dan kekurangan tersendiri. Berdasarkan pengertian CV di atas, berikut ini adalah beberapa kelebihan dan kekurangan Perseroan Terbatas:

\section{Kelebihan Perseroan Terbatas}

- Perseroan Terbatas merupakan badan hukum sehingga kelangsungan hidupnya terjamin, meskipun terjadi pergantian pemilik.

- Para pemilik saham hanya bertanggungjawab sebesar modal yang ditanamkan.

- Pemindahan saham dari satu pemilik saham kepada pemegang saham lainnya dapat dilakukan dengan mudah.

- Perseroan Terbatas dapat memperluas usahanya dengan mudah karena kemudahan dalam mendapatkan tambahan modal.

- Sumber-sumber modal Perseroan Terbatas dikelola oleh para spesialis sehingga penggunaannya lebih efektif dan efisien.

\section{Kekurangan Perseroan Terbatas}

- Pendirian Perseroan Terbatas membutuhkan biaya yang cukup besar.

- Proses pendirian Perseroan Terbatas cenderung lebih sulit dibandingkan jenis badan usaha lainnya.

- Sebagian pemegang saham sering menganggap perusahaan Perseroan Terbatas merahasiakan keuntungan yang didapatkan.

- Perseroan Terbatas dikenakan pajak karena merupakan salah satu subjek pakak.

\section{$\underline{\text { Prosedur Hukum Pengambilalihan Perseroan Terbatas }}$}

\section{A. Proses Pengambilalihan melalui Direksi Perseroan}


Menurut Pasal 125 ayat (1) UUPT, Pengambilalihan dilakukan dengan cara pengambilalihan saham yang telah dikeluarkan dan/atau akan dikeluarkan oleh Perseroan melalui Direksi Perseroan atau langsung dari pemegang saham. Dimana yang dapat melakukan Pengambilalihan dapat berupa badan hukum atau orang perseorangan. Pengambilalihan saham yang dimaksud Pasal 125 ayat (1) adalah Pengambilalihan yang mengakibatkan beralihnya pengendalian terhadap Perseroan nantinya seperti yang dimaksud dalam Pasal 7 angka 11 UUPT. Berikut ini adalah proses Pengambilalihan melalui Direksi Perseroan:

\section{Keputusan RUPS}

Pasal 125 ayat (4) UUPT diatur mengenai pengambilalihan yang dilakukan oleh badan hukum berbentuk Perseroan, Direksi sebelum melakukan perbuatan hukum pengambilalihan harus berdasarkan RUPS yang memenuhi kuorum kehadiran dan ketentuan tentang persyaratan pengambilan keputusan RUPS sebagaimana dimaksud dalam Pasal 89 UUPT yaitu paling sedikit $3 / 4$ (tiga perempat) bagian dari jumlah seluruh saham dengan hak suara hadir atau diwakili dalam RUPS dan keputusan adalah sah jika disetujui paling sedikit 3/4 (tiga perempat) bagian dari jumlah suara yang dikeluarkan, kecuali anggaran dasar menentukan kuorum kehadiran dan/atau ketentuan RUPS yang lebih besar.

\section{Pemberitahuan kepada Direksi Perseroan}

Menurut Pasal 125 ayat (5) UUPT, dalam hal pengambilalihan dilakukan oleh Direksi, pihak yang akan mengambil alih menyampaikan maksudnya untuk melakukan Pengambilalihan kepada Direksi Perseroan yang akan diambil alih.

\section{Penyusunan Rancangan Pengambilalihan}

Menurut Pasal 125 ayat (6) UUPT Direksi Perseroan yang akan diambilalih dengan persetujuan komisaris masing-masing Perseroan menyusun rancangan pengambilalihan yang memuat sekurang-kurangnya hal-hal sebagai berikut :

1. Nama dan tempat kedudukan dari Perseroan yang akan diambilalih dan perseroan yang akan mengambilalih. 
2. Alasan serta penjelasan Direksi Perseroan yang akan mengambilalih dan Direksi Perseroan yang akan diambilalih.

3. Laporan Keuangan sebagaimana dimaksud dalam Pasal 66 ayat (2) UUPT untuk tahun buku terakhir dari Perseroan yang akan mengambilalih dan Perseroan yang akan diambilalih.

4. Tata cara penilaian dan konversi saham dari perseroan yang akan diambilalih terhadap saham penukarnya apabila pembayaran pengambilalihan dengan saham.

5. Jumlah saham yang akan diambilalih.

6. Kesiapan pendanaan.

7. Neraca konsolidasi performa Perseroan yang akan mengambilalih setelah pengambilalihan yang disusun sesuai dengan prinsip akuntasi yang berlaku umum di Indonesia.

8. Cara penyelesaian hak Pemegang Saham yang tidak setuju terhadap pengambilalihan

9. Cara penyelesaian status, hak dan kewajiban anggota Direksi, Komisaris dan Karyawan Perseoran yang diambilalih.

10. Perkiraan jangka waktu pelaksanaan pengambilalihan, termasuk jangka waktu pemberian kuasa pengalihan saham dari Pemegang Saham kepada Direksi Perseroan.

11. Rancangan perubahan Anggaran Dasar Perseroan hasil pengambilalihan jika ada.

\section{Pengumuman Ringkasan Rancangan}

Selanjutnya, Direksi Perseroan wajib mengumumkan ringkasan rancangan paling sedikit dalam 1 (satu) surat kabar dan mengumumkan secara tertulis kepada karyawan dari Perseroan yang akan melakukan Pengambilalihan dalam jangka waktu paling lambat 30 (tiga puluh) hari sebelum pemanggilan RUPS (Pasal 127 ayat (2) UUPT). Pengumuman sebagaimana dimaksud tersebut memuat juga pemberitahuan bahwa pihak yang berkepentingan dapat memperoleh rancangan Pengambilalihan di kantor Perseroan terhitung sejak tanggal pengumuman sampai tanggal RUPS diselenggarakan.

\section{Pengajuan Keberatan Kreditor}


Kreditor dapat mengajukan keberatan kepada Perseroan dalam jangka waktu paling lambat 14 (empat belas) hari setelah pengumuman mengenai Pengambilalihan sesuai dengan rancangan tersebut. Apabila dalam jangka waktu tersebut kreditor tidak mengajukan keberatan, kreditor dianggap menyetujui Pengambilalihan tersebut. Dalam hal keberatan kreditor sampai dengan tanggal diselenggarakan RUPS tidak dapat diselesaikan oleh Direksi, keberatan tersebut harus disampaikan dalam RUPS guna mendapat penyelesaian. Selama masa penyelesaian belum tercapai, Pengambilalihan tidak dapat dilaksanakan.

\section{Pembuatan Akta Pengambilalihan dihadapan Notaris}

Menurut Pasal 128 ayat (1) menyatakan, Rancangan Pengambilalihan yang telah disetujui RUPS dituangkan ke dalam akta Pengambilalihan yang dibuat dihadapan notaris dalam bahasa Indonesia.

\section{Pemberitahuan kepada Menteri}

Kemudian, salinan akta Pengambilalihan Perseroan wajib dilampirkan pada penyampaian pemberitahuan kepada Menteri tentang perubahan anggaran dasar sebagaimana yang dimaksud dalam Pasal 21 ayat (3) UUPT. Ketentuan sebagaimana dimaksud dalam pasal 29 dan Pasal 30 UUPT mengenai Daftar Perseroan dan Pengumuman berlaku juga bagi Pengambilalihan. Ketentuan lebih lanjut mengenai Pengambilalihan Perseroan diatur dengan peraturan Pemerintah.

\section{Pengumuman Hasil Pengambilalihan}

Menurut Pasal 133 ayat (2) UUPT, Direksi Perseroan yang sahamnya diambilalih wajib mengumumkan hasil Pengambilalihan tersebut dalam 1 (satu) surat kabar atau lebih dalam jangka waktu paling lambat 30 (tiga puluh) hari terhitung sejak tanggal berlakunya Penggambilalihan tersebut. 


\section{PENUTUP}

\section{A. Kesimpulan}

1. Perseroan Terbatas (PT), dulu disebut juga Naamloze Vennootschhap (NV) adalah suatu badan hukum untuk menjalankan usaha yang memiliki modal terdiri dari sahamsaham, yang pemiliknya memiliki bagian sebanyak saham yang dimilikinya. Karena modalnya terdiri dari saham-saham yang dapat diperjualbelikan, perubahan kepemilikan perusahaan dapat dilakukan tanpa perlu membubarkan perusahaan.

2. Untuk mendirikan PT, harus dengan menggunakan akta resmi (akta yang dibuat oleh notaris) yang di dalamnya dicantumkan nama lain dari perseroan terbatas, modal, bidang usaha, alamat perusahaan, dan lain-lain.

\section{B. Saran}

Semoga dengan adanya makalah ini dapat membantu pemakalah dan teman-teman dalam memahami konsep Perseoran Terbatas dan pengaplikasiannya. Pemakalah berharap kritik dan saran yang membangun dari pembaca. 